\title{
Delay in Ovulation and Fertilization and Asynchronous Pronuclear Development in Aged Hamsters
}

\author{
Hiroyuki SUZUKI, Miho MORIGUCHI, Ryoko KIDA and Yuetsu MORO
}

Faculty of Agriculture, Hirosaki University, Hirosaki 036, Japan

\begin{abstract}
Ova were collected from young (9-12-week old) and aged (43-53-week old) golden hamsters at various times before and after fertilization to decide the timing of ovulation, sperm penetration and pronuclear formation. Ovulation was delayed $1 \mathrm{~h}$ in the aged animals, although overall ovulation rate did not differ statistically between young and aged animals. Sperm penetration also showed another $1 \mathrm{~h}$ delay in aged hamsters. The types of abnormalities during early fertilization were asynchronous development of male and female pronuclei, polyspermy, polygyny and pycnosis. Asynchronous development of the male and female pronuclei, mainly a delay in the development of the male pronucleus, was found more often in the aged females $(8.2 \%)$, contrasting $3.1 \%(\mathrm{P}<0.01)$ in the young females. Polyspermy accounted for a small proportion of the abnormalities in both groups ( 0.5 and $0.4 \%$ in the young and aged groups, respectively), whereas abnormalities observed only in the aged group were polygyny (5.5\%) and pycnosis $(0.4 \%)$. It is suggested that increased abnormalities of fertilization observed in the aged hamsters (approximately $15 \%$ of the total ova) may be directly related to delayed ovulation and fertilization attributed to defective ova and deteriorated reproductive ability of the aged females. These delays in ovulation and fertilization may be the main factors causing the preimplantation wastage of embryos in the aged hamsters.
\end{abstract}

Key words: Asynchronous PN development, Delayed ovulation, Delayed fertilization, Aged hamsters.

(J. Reprod. Dev. 42: 15-22, 1996)

$\mathbf{T}$ he fecundity of mammals gradually declines with age and the cessation of the reproductive ability is taken as the beginning of senescence [16]. A decline in reproductive capacity with increasing age can be characterized by a progressive reduction in litter size in female golden hamsters [7-12], as well as in other rodents [1315]. A decline in reproductive capacity of aged female hamsters depends upon an increase in preimplantation loss and an increase in resorption of implanted embryos [8-12]. The decline is not caused primarily by a depletion of oocytes, since the number of ovulated ova remains relatively con-

Accepted for publication: October 20, 1995

Correspondence: $\mathrm{H}$. Suzuki stant throughout the reproductive life, at least until just before the cessation of the estrous cycle [3, $4,9,10]$. Several studies on the decline of the reproductive ability have revealed that embryos from old animals show a developmental delay before and during implantation $[10,11,15,16]$, and that a progressive deterioration in uterine adaptability to pregnancy is noted in aged hamsters [11, 17]. The increased number of retarded embryos in aged hamsters $[15,17]$ is an indication of the impaired viability of the embryos. Parkening and Soderwall $[16,18]$ have noted delayed fertilization in the majority of ova in the aged hamsters and suggested that this defect may be the primary factor causing the preimplantation wastage of embryos. Since it is well known that the ovum 
remains fertilizable for longer than it retains the capacity to develop to a normal embryo, the synchronization of ovulation and fertilization is of utmost importance for normal development [19]. Our preliminary study suggested that a reduced ability to reproduce in the aged hamster may be due to an increased proportion of abnormal ova before preimplantation [20]. In order to clarify the causes of preimplantation loss of embryos in the aged hamster, the process of early fertilization was examined in both young and aged hamsters. In the present study, we compared the timing of ovulation, sperm penetration and pronuclear formation in young and aged hamsters.

\section{Materials and Methods}

\section{Animals}

Golden hamsters (Mesocricetus auratus) were kept under conditions of constant temperature (21-23 C) and a cycle of 14-h light (0500 h-1900 h) and 10$\mathrm{h}$ dark. They were given laboratory Chow (MF, Oriental Yeast Co. Ltd., Tokyo) and water ad libitum. The estrous cycle of each female was determined according to Orsini [21]. The day on which postovulatory vaginal discharge occurred was designated as the 1st day of the estrous cycle. Hamsters that had exhibited at least three consecutive cycles were considered to be regular cyclic. Our preliminary study showed that the female hamsters exhibited a marked decline in litter size after 43 weeks of age [20]. A total of 173 virgin females were mated at 9-12 weeks of age and randomly assigned to young (9-12 weeks of age) or aged groups (43-53 weeks of age). The females in the aged group were mated repeatedly at intervals of 10-12 weeks until examination at 43-53 weeks of age. Young males with proven fertility were used for mating. In the evening on the 4th day of the estrous cycle, the females were caged with the males and checked for the presence of spermatozoa in the vaginal smear just before the examination for ovulation and fertilization.

\section{Ovulation and fertilization rates}

The successfully mated hamsters were sedated with ether and killed by cervical dislocation every hour from $0000 \mathrm{~h}$ through $1100 \mathrm{~h}$ ( $24 \mathrm{~h}$ clock). The ovary and oviduct were removed keeping the ovarian sac intact, placed in Dulbecco's phosphate buffer solution (DPBS) and then the sac was dissected away under a stereoscopic microscope. At $0000 \mathrm{~h}-0300 \mathrm{~h}$, special attention was given to searching for the ova freshly ovulated and not descended to the ampulla of the oviduct. The oviduct was then carefully dissected out from the ovary. Ova with the cumulus mass were recovered either by puncture of the ampullary regions or by flushing the entire oviduct according to the time of recovery. The ovary was checked the number of ovulation points and the fully grown, unruptured antral follicles under a dissecting microscope. Percentage of ova shed was calculated as the ratio of the number of ova ovulated to the total number of ovulated ova and antral follicles remaining in the ovary.

\section{Morphological examination of fertilization}

The cumulus mass adhering to ova was dispersed by $0.1 \%$ hyaluronidase in Ca-free DPBS. Cumulus-free ova were washed in DPBS, prefixed in $2.5 \%$ glutaraldehyde (phosphate buffered, $\mathrm{pH}$ 7.3) for $1 \mathrm{~min}$ and then fixed in 10\% neutral formalin overnight. After fixation, ova were washed in distilled water and mounted on glass slides and held firmly in place under coverslips with spots of a paraffin/vaseline mixture (1:9) on each corner.

Table 1. Explanation of five developmental stages of the male and female pronuclei (PN)

\begin{tabular}{|c|c|c|}
\hline Stage & Male PN & Female PN \\
\hline PN-1 & $\begin{array}{l}\text { Spermatozoon is penetrating or penetrated completely } \\
\text { into the ooplasm, or sperm head is starting to decondense. }\end{array}$ & $\begin{array}{l}\text { Second meiotic division has just started, being in } \\
\text { anaphase II. }\end{array}$ \\
\hline PN-2 & Sperm head is fully decondensed. & Chromosomes are in telophase II. \\
\hline PN-3 & Nuclear envelope is starting to form. & $\begin{array}{l}\text { Nuclear envelope is starting to form, second polar } \\
\text { body is extruded. }\end{array}$ \\
\hline PN-4 & $\begin{array}{l}\text { Small spherical PN, containing a few nucleoli, } \\
\text { is surrounded by a complete nuclear envelope. }\end{array}$ & Same as Male PN-4. \\
\hline PN-5 & PN reaches maximum size, containing numerous nucleoli. & Same as Male PN-5. \\
\hline
\end{tabular}


The ova were then stained with $0.25 \%$ aceto:lacmoid and examined using a phase contrast microscope.

The sequence of sperm penetration into ooplasm, sperm head decondensation, completion of the second meiotic division, and male and female pronuclear development were recorded and classified microscopically into five developmental stages as shown in Table 1. The criteria were modified for hamster ova in this study, based on the report on bovine oocytes fertilized in vitro by $\mathrm{Xu}$ and Greve [22].

\section{Statistical analyses}

Statistical significance of the data was analyzed by Student's $t$-test and $\chi^{2}$ test [23].

\section{Results}

\section{Ovulation and fertilization}

Table 2 shows mean percentages of follicles ovulated, ova with sperm penetration and ova with pronuclear formation in young and aged hamsters. In the young group, ovulation was observed even at $0000 \mathrm{~h}$ in 2 out of 7 females, and the percentage of follicles ovulated was $16.2 \%(19 / 117)$, whereas in the aged group no ovulation was found at $0000 \mathrm{~h}$. At $0100 \mathrm{~h}$ ovulation had occurred in all young females, and proportion of ovulated follicles increased from $0100 \mathrm{~h}(57.3 \%, 51 / 89)$ to $0200 \mathrm{~h}$
(75.0\%, 69/92). In contrast, only 3 out of 7 females in the aged group had ovulated at $0100 \mathrm{~h}(18.2 \%$, $18 / 99)$, and the percentage of follicles ovulated increased from $0200 \mathrm{~h}(64.0 \%, 57 / 89)$ to $0300 \mathrm{~h}(89.0 \%$, $89 / 100)$. Percentage of oocytes ovulated reached approximately $90 \%$ at $0300 \mathrm{~h}$ in both young and aged groups, and the number of ova ovulated after $0400 \mathrm{~h}$ was not significantly different between two groups (13.4 \pm 0.3 and $14.0 \pm 0.4$, s.e.m., for young and aged groups, respectively). First evidence of sperm penetration and pronuclear formation was observed at $0300 \mathrm{~h}$ and $0500 \mathrm{~h}$ in the young group $(11.3 \%, 11 / 97$ and $4.8 \%, 7 / 146$, respectively) and $0500 \mathrm{~h}$ and $0600 \mathrm{~h}$ in the aged group $(11.3 \%, 12 / 106$ and $0.8 \%, 1 / 122$, respectively).

From the median ovulation time (time when approximately $50 \%$ of the follicles had ovulated), ovulation was judged to have occurred at $0100 \mathrm{~h}$ in the young females and at $0200 \mathrm{~h}$ in the aged females, showing $1 \mathrm{~h}$ delay in the ovulation process in the aged group (Table 2). Similarly, the time of the median sperm penetration and pronuclear formation was at $0500 \mathrm{~h}$ and $0900 \mathrm{~h}$ in the young females and at $0700 \mathrm{~h}$ and $1100 \mathrm{~h}$ in the aged females, respectively. The pronucleus was formed $4 \mathrm{~h}$ after sperm penetration in both groups. These observations indicate that there was further $1 \mathrm{~h}$ delay in sperm penetration in the aged females. Rates of sperm penetration and pronuclear formation in the aged group were significantly lower

Table 2. Percentages of follicles ovulated, ova with sperm penetration and ova with pronuclear formation in young and aged hamsters at each time point from $0000 \mathrm{~h}$ to $1100 \mathrm{~h}^{*}$

\begin{tabular}{|c|c|c|c|c|c|c|c|c|}
\hline \multirow{2}{*}{$\begin{array}{l}\text { Time } \\
\text { ( } 24 \text { h clock) }\end{array}$} & \multicolumn{2}{|c|}{ No. of animals } & \multicolumn{2}{|c|}{$\begin{array}{c}\% \text { of follicles } \\
\text { ovulated }\end{array}$} & \multicolumn{2}{|c|}{$\begin{array}{c}\% \text { with sperm } \\
\text { penetration }\end{array}$} & \multicolumn{2}{|c|}{$\begin{array}{c}\% \text { with pronuclear } \\
\text { formation }\end{array}$} \\
\hline & $\begin{array}{c}\text { Young } \\
\text { (Ovulated }\end{array}$ & $\begin{array}{l}\text { Aged } \\
\text { Total) }\end{array}$ & Young & Aged & Young & Aged & Young & Aged \\
\hline $0000 \mathrm{~h}$ & $2 / 7$ & $0 / 7$ & 16.2 & 0 & 0 & 0 & 0 & 0 \\
\hline $0100 \mathrm{~h}$ & $6 / 6$ & $2 / 7$ & $57.3^{a}$ & $18.2^{\mathrm{b}}$ & 0 & 0 & 0 & 0 \\
\hline $0200 \mathrm{~h}$ & $6 / 6$ & $5 / 5$ & 75.0 & 64.0 & 0 & 0 & 0 & 0 \\
\hline $0300 \mathrm{~h}$ & $9 / 9$ & $6 / 6$ & $98.9^{a}$ & $89.0^{\mathrm{b}}$ & 11.3 & 0 & 0 & 0 \\
\hline $0400 \mathrm{~h}$ & $7 / 7$ & $6 / 6$ & 92.7 & 90.6 & 28.1 & 0 & 0 & 0 \\
\hline $0500 \mathrm{~h}$ & $11 / 11$ & $7 / 7$ & 95.9 & 98.3 & $52.5^{\mathrm{a}}$ & $11.3^{\mathrm{b}}$ & 4.8 & 0 \\
\hline $0600 \mathrm{~h}$ & $11 / 11$ & $8 / 8$ & 94.0 & 100 & $51.0^{\mathrm{a}}$ & $20.5^{\mathrm{b}}$ & $21.8^{a}$ & $0.8^{b}$ \\
\hline $0700 \mathrm{~h}$ & $8 / 8$ & $5 / 5$ & 97.2 & 100 & $73.1^{\mathrm{a}}$ & $50.0^{\mathrm{b}}$ & $33.3^{a}$ & $11.3^{\mathrm{b}}$ \\
\hline $0800 \mathrm{~h}$ & $5 / 5$ & $5 / 5$ & 100 & 100 & $80.3^{a}$ & $63.9^{c}$ & $25.0^{\mathrm{a}}$ & $6.9^{b}$ \\
\hline $0900 \mathrm{~h}$ & $10 / 10$ & $14 / 14$ & 100 & 100 & $89.7^{\mathrm{a}}$ & $56.5^{\mathrm{b}}$ & $86.5^{a}$ & $44.4^{\mathrm{b}}$ \\
\hline $1000 \mathrm{~h}$ & $5 / 5$ & $5 / 5$ & 100 & 100 & $91.0^{\mathrm{a}}$ & $69.2^{b}$ & $79.1^{\mathrm{a}}$ & $38.5^{\mathrm{b}}$ \\
\hline $1100 \mathrm{~h}$ & $7 / 7$ & $6 / 6$ & 100 & 100 & $94.4^{\mathrm{a}}$ & $84.7^{\mathrm{c}}$ & $90.0^{\mathrm{a}}$ & $73.6^{\mathrm{b}}$ \\
\hline
\end{tabular}

*, Percentages with different superscripts in each category at the same time point differ significantly between young and aged groups $(\mathrm{P}<0.01$ between $\mathrm{a}$ and $\mathrm{b}, \mathrm{P}<0.05$ between a and $\mathrm{c})$. 
than those in the young group (Table 2). The percentage of ova without pronuclear formation indicates that unfertilized / degenerated ova exceeded $25 \%$ in the aged group at $1100 \mathrm{~h}$ in contrast to about $10 \%$ in the young group (Tables 2 and 5).

\section{Abnormalities in fertilization}

The developmental stages of the male and fe-

Table 3. Relation in the developmental stages of male (MPN) and female pronuclei (FPN) in ova derived from young and aged groups at each time point from $0000 \mathrm{~h}$ to $1100 \mathrm{~h}^{*}$

\begin{tabular}{|c|c|c|c|c|c|c|c|c|c|c|c|}
\hline \multirow{2}{*}{\multicolumn{2}{|c|}{$\begin{array}{l}\text { Time } \\
\text { (24h clock) }\end{array}$}} & \multicolumn{5}{|c|}{ Young group } & \multicolumn{5}{|c|}{ Aged group } \\
\hline & & \multirow{2}{*}{$\begin{array}{c}\text { FPN-1 } \\
5\end{array}$} & \multirow{2}{*}{$\begin{array}{c}\text { FPN-2 } \\
\mathbf{1}\end{array}$} & \multirow[t]{2}{*}{ FPN-3 } & \multirow[t]{2}{*}{ FPN-4 } & \multirow[t]{2}{*}{ FPN-5 } & \multirow[t]{2}{*}{ FPN-1 } & \multirow[t]{2}{*}{ FPN-2 } & \multirow[t]{2}{*}{ FPN-3 } & \multirow[t]{2}{*}{ FPN-4 } & \multirow[t]{2}{*}{ FPN-5 } \\
\hline $0300 \mathrm{~h}$ & MPN-1 & & & & & & & & & & \\
\hline & MPN-2 & 3 & & 1 & & & & & & & \\
\hline & MPN-3 & & & 1 & & & & & & & \\
\hline & MPN-4 & & & & & & & & & & \\
\hline & MPN-5 & & & & & & - & & & . & \\
\hline \multirow{5}{*}{$\overline{0400 \mathrm{~h}}$} & $\overline{\mathrm{MPN}}-1$ & & & & & & & & & & \\
\hline & MPN-2 & 3 & 1 & & & & & & & & \\
\hline & MPN-3 & 15 & 5 & 3 & & & & & & & \\
\hline & MPN-4 & & & & & & & & & & \\
\hline & MPN-5 & 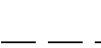 & - & - & - & 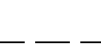 & - & & 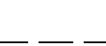 & $\ldots$ & \\
\hline \multirow[t]{5}{*}{$0500 \mathrm{~h}$} & $\overline{\mathrm{MPN}}-1$ & 11 & 5 & & & & 5 & & & & \\
\hline & MPN-2 & 21 & 16 & 5 & & & 6 & & 1 & & \\
\hline & MPN-3 & & & 4 & 1 & & & & & & \\
\hline & MPN-4 & & & & 4 & & & & & & \\
\hline & MPN-5 & - & 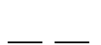 & - & - & 7 & - & & 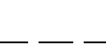 & & \\
\hline \multirow[t]{5}{*}{$\overline{0600 \mathrm{~h}}$} & $\overline{\mathrm{MPN}}-1$ & 11 & 1 & 1 & & & 4 & & & & \\
\hline & MPN-2 & 7 & 12 & 2 & & & 8 & 8 & 2 & & \\
\hline & MPN-3 & & & 5 & & & & & & & \\
\hline & MPN-4 & & & & 3 & & & & & 2 & \\
\hline & MPN-5 & & 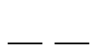 & 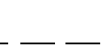 & - & 32 & - & 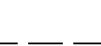 & $\ldots$ & 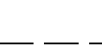 & 1 \\
\hline \multirow[t]{5}{*}{$0700 \mathrm{~h}$} & MPN-1 & 7 & 1 & & 1 & & 3 & 3 & 2 & 1 & \\
\hline & MPN-2 & 8 & 12 & 3 & 1 & & 3 & 3 & 1 & & 1 \\
\hline & MPN-3 & & & 5 & & & & 1 & & & \\
\hline & MPN-4 & & & & 1 & & & & & 5 & 2 \\
\hline & MPN-5 & & 1 & & 1 & 36 & _ & & & 1 & 3 \\
\hline \multirow[t]{5}{*}{$0800 \mathrm{~h}$} & MPN-1 & 4 & & 3 & & & 12 & & & & \\
\hline & MPN-2 & & 15 & 3 & & & 1 & 10 & 5 & 4 & \\
\hline & MPN-3 & & & 2 & 5 & 1 & & 1 & & 1 & \\
\hline & MPN-4 & & & & 9 & 2 & & & & 6 & 2 \\
\hline & MPN-5 & & 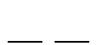 & _. & - & 17 & _ & - & & & 4 \\
\hline \multirow[t]{5}{*}{$0900 \mathrm{~h}$} & $\overline{\mathrm{MPN}}-1$ & 2 & 1 & & & 1 & 8 & 5 & & & \\
\hline & MPN-2 & & 2 & 1 & 2 & 7 & 2 & 14 & 1 & 5 & 7 \\
\hline & MPN-3 & & & & & & & & & 1 & \\
\hline & MPN-4 & & & & 6 & & & 1 & & 8 & 1 \\
\hline & MPN-5 & & $\ldots$ & 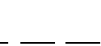 & 2 & 119 & 1 & 1 & 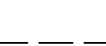 & 2 & 85 \\
\hline \multirow[t]{5}{*}{$1000 \mathrm{~h}$} & MPN-1 & & & & & & 1 & 1 & 2 & & \\
\hline & MPN-2 & & 2 & 1 & 1 & & 1 & 3 & 4 & 5 & \\
\hline & MPN-3 & & & & & & & & 1 & 2 & \\
\hline & MPN-4 & & & & & 2 & & & & 1 & \\
\hline & MPN-5 & & & & 2 & 53 & & & & 3 & 30 \\
\hline$\overline{1100 \mathrm{~h}}$ & $\overline{\mathrm{MPN}}-1$ & & & & & & & $\overline{1}$ & & & \\
\hline & MPN-2 & & & & & & & & & 1 & \\
\hline & MPN-3 & & & & & & & & & & \\
\hline & MPN-4 & & & & & & & & & 1 & 1 \\
\hline & MPN-5 & & & & 1 & 81 & & & & 1 & 52 \\
\hline
\end{tabular}

*, The bold numbers represent the number of ova in which the male and female pronuclei are synchronous; the italic numbers represent the number of ova in which the both pronuclei are asynchronous. See details in text. Table does not include numbers of ova judged as unfertilized, polyspermy, digyny and pycnosis. 
male pronuclei within an individual ovum were not always synchronous. Table 3 shows synchrony/asynchrony of the male and female pronuclei. According to $\mathrm{Xu}$ and Greve [22], the ovum having two pronuclei at identical stages or exhibiting only one stage difference was regarded as representing synchronous development of male and female pronuclei. On the other hand, the ovum, with pronuclei which were two or more stages apart, was regarded as asynchronous. The proportion of asynchronous ova was $0-7 \%$ in the young group and $0-14 \%$ in the aged group at $0600 \mathrm{~h}$ to $1100 \mathrm{~h}$ period (Table 4). The value tended to be higher at $0700 \mathrm{~h}$ to $1000 \mathrm{~h}$ period. Table 5 showed the percentage of abnormalities observed in the ova recovered from the young and aged hamsters.
Overall proportion of ova showing asynchronous development of the pronuclei to the ova with sperm penetration was significantly different between young $(3.1 \%, 19 / 610)$ and aged females $(8.2 \%, 30 /$ $365, \mathrm{P}<0.01)$. A very small proportion of delays was noted in the female pronucleus in both young $(1 / 610)$ and aged $(3 / 365)$ females, showing that asynchrony is mainly caused by the delay in male pronuclear development.

The other types of abnormalities were polyspermy, polygyny and pycnosis (Table 5). Polyspermy was observed in both groups, but polygyny and pycnosis were found only in the aged group. Overall frequencies of polyspermy (mean \pm s.e.m.) were $0.5 \pm 0.5 \%$ and $0.4 \pm 0.4 \%$ in the young and aged groups, respectively, and all instances were di-

Table 4. Percentage of asynchronous development of male and female pronuclei in ova derived from young and aged groups at each time point from $0300 \mathrm{~h}$ to $1100 \mathrm{~h}$

\begin{tabular}{|c|c|c|c|c|}
\hline \multirow[b]{2}{*}{$\begin{array}{l}\text { Time } \\
\text { (24 h clock) }\end{array}$} & \multicolumn{2}{|c|}{ Young group } & \multicolumn{2}{|c|}{ Aged group } \\
\hline & $\begin{array}{l}\text { No. ova } \\
\text { penetrated }\end{array}$ & $\%$ asynchrony & $\begin{array}{l}\text { No. ova } \\
\text { penetrated* }\end{array}$ & $\%$ asynchrony \\
\hline $0300 \mathrm{~h}$ & 11 & 0 & $0^{* *}$ & 0 \\
\hline $0400 \mathrm{~h}$ & 27 & 0 & $0^{* *}$ & 0 \\
\hline $0500 \mathrm{~h}$ & 74 & 0 & 12 & 0 \\
\hline $0600 \mathrm{~h}$ & 74 & 1.2 & 25 & 0 \\
\hline $0700 \mathrm{~h}$ & 77 & 3.9 & 29 & 13.8 \\
\hline $0800 \mathrm{~h}$ & 61 & 6.6 & 46 & 8.7 \\
\hline $0900 \mathrm{~h}$ & 143 & 7.0 & 142 & 10.6 \\
\hline $1000 \mathrm{~h}$ & 61 & 1.6 & 54 & 13.0 \\
\hline $1100 \mathrm{~h}$ & 82 & 0 & 57 & 1.8 \\
\hline
\end{tabular}

*, Data do not include numbers of ova judged as unfertilized, polyspermy, digyny and pycnosis.

**, Sperm penetration was not observed.

Table 5. Percentage of abnormalities in fertilization observed in ova derived from young and aged groups*

\begin{tabular}{|c|c|c|c|c|}
\hline \multirow{2}{*}{$\begin{array}{c}\text { Type of } \\
\text { abnormalities }\end{array}$} & \multicolumn{2}{|c|}{ Young group } & \multicolumn{2}{|c|}{ Aged group } \\
\hline & $\begin{array}{l}\text { No. ova } \\
\text { penetrated }\end{array}$ & $\%$ abnormalities & $\begin{array}{l}\text { No. ova } \\
\text { penetrated }\end{array}$ & $\%$ abnormalities \\
\hline $\begin{array}{l}\text { Asynchronous develop } \\
\text { of male and female } \\
\text { proneclei }\end{array}$ & $610^{* *}$ & $3.1^{\mathrm{a}}$ & $365^{\star *}$ & $8.2^{\mathrm{b}}$ \\
\hline Polyspermy & 613 & 0.5 & 388 & 0.4 \\
\hline Digyny & 613 & 0 & 388 & 5.5 \\
\hline Pycnosis & 613 & 0 & 388 & 0.4 \\
\hline Unfertilized $^{* * *}$ & 90 & $5.6^{\mathrm{a}}$ & 72 & $15.3^{c}$ \\
\hline
\end{tabular}

*, Percentages with different superscripts differ significantly between young and aged groups $(\mathrm{P}<0.01$ between a and $b ; \mathrm{P}<0.05$ between a and $c$ ).

**, Data do not include numbers of ova judged as unfertilized, polyspermy, digyny and pycnosis.

***, Data obtained at $1100 \mathrm{~h}$ were shown. 
spermy. Polygyny observed in the present study was digyny, i.e. the ovum having three pronuclei and a sperm tail in the ooplasm in addition to an extruded polar body. Frequency of digyny was identified in $5.5 \pm 2.7 \%$ and that of pycnosis was $0.4 \pm 0.4 \%$.

\section{Discussion}

\section{Ovulation and fertilization}

The number of ova ovulated was relatively similar in both young and aged hamsters, after the ovulation rate reached more than $90 \%$ (after $0400 \mathrm{~h}$ in this study). This finding is in agreement with other studies examining the ovulation in aged hamsters $[9,10,12,18,24,25]$, mice $[2,13]$ and rats [14]. However, little attention has been paid to the timing of ovulation. In the present study, both ovulation and sperm penetration were found to be delayed in aged hamsters. Parkening and Soderwall $[12,18]$ have reported that the majority of ova recovered from aged hamsters mated with young males exhibited a 2 to $5 \mathrm{~h}$ delay in fertilization. These authors did not examine the exact time of ovulation. However, considering the finding that ovulation occurs $8 \mathrm{~h}$ after estrus in the hamster [26], a tendency toward delayed ovulation can be found in their results $[12,18]$. Furthermore, according to their data, the mean number of ova collected at $1 \mathrm{~h}$ after the estimated time of ovulation was significantly lower in aged hamsters compared with young hamsters. However, there was no difference between the mean number of ova collected from aged hamsters at $2 \mathrm{~h}$ after the estimated time of ovulation and those collected from young females at $1 \mathrm{~h}$. The delay in ovulation is probably caused by an interplay of many agerelated changes in several organs. Physiological factors related to such alterations in aged females may include changes in tissue and organ sensitivity to the anterior pituitary secretions, changes in ovarian function, and progressive hormonal imbalance of several organs [1-6].

When ovulation was pharmacologically delayed for up to $48 \mathrm{~h}$ in female rats via pentobarbital injection, an increase in abnormalities of preimplantation and postimplantaion embryos was observed [4]. Therefore, preovulatory aging of oocytes attributed to delayed ovulation may cause a decline in reproductive capacity in females.
The delay in fertilization in the aged females seems to be attributed to age-related changes in progesterone secretion around the time of ovulation. It has been reported that aged hamsters exhibit considerable variability in plasma progesterone levels during early pregnancy as compared to young females [24]. Progesterone is found to affect sperm transport [27], time of estrus and ovulation [28], and the ratio of circulating gonadotropins [29] in the hamster, whereas sperm incubation in the uteri of aged hamsters is shown to have no effect on in vitro fertilization [25].

\section{Abnormalities in fertilization}

In our observations on the sequential changes during early fertilization, some ova showed asynchronous development of male and female pronuclei and other types of abnormalities, such as polyspermy, polygyny and pycnosis. Delay in male pronucleus development and polygyny were the predominant abnormal features in the aged group. Failure in sperm head decondensation and retardation in pronuclear development may be considered to be the main causes for asynchronous development of male and female pronuclei. It has been reported that the egg cytoplasmic factor(s) control the development of male pronucleus [30, 31]. The asynchronous pronuclear development observed in the present study suggests that the factor known as the male pronucleus growth factor (MPGF) [32] or sperm pronucleus development factor (SPDF) [30, 31] may differ from the factor regulating the development of the female pronucleus. Moreover, if MPGF and SPDF are involved, then the present results would indicate that these factors are inadequate in amount or are inactivated in the ova of aged hamsters. These substances have been reported to be readily inactivated or fail to be produced when eggs are matured in vitro under suboptimal conditions [33]. Recently, it has been reported that glutathione is important in the acquisition and maintenance of sperm nuclear decondensing activity in the hamster oocytes [34]. Further studies will be needed to decide changes in the levels and functions of the egg cytoplasmic factors during maternal aging.

Polygyny may arise through failure in polar body formation at the second meiotic division, since the extra pronucleus is female in origin. During anaphase II the bivalents move to opposite ends of the spindle, which rotates gradually through $90^{\circ}$, 
so that the axis becomes radially orientated in the hamster [30]. The rotation is completed by early telophase II when the egg-surface near the chromosomes normally forms a slight elevation. In the present study, however, the rotation of the spindle was not completed in some of ova from aged hamsters. It is possible that the oocytes exhibiting abnormal telophase II may not always extrude the second polar body, thereby causing triploid with two female pronuclei and one male pronucleus. These observations suggest that quality of the oocytes ovulated by individual aged females may not be uniform, and that the age-related alterations of oocytes may occur within the follicles. Mizoguchi and Dukelow [25] have also noted that aged hamsters tend to ovulate morphologically abnormal oocytes, incidence of which was $6.9 \%$ contrasting with $0.5 \%$ in young females. It is reported, in mice [35] and rats [36], that ultrastructure of the preovulatory oocytes undergoes age-related changes and some biochemical activities are also altered in the aged animals, possibly leading to increase in abnormalities in fertilization and reduced viability in embryonic development. It is well accepted that post-ovulatory aging of the ova induced by delaying artificial insemination or mating cause abnormal fertilization, such as polyspermy and polygyny [19] and reduces the number of young born as the delay increases.

Studies on retarded embryonic development in the embryo transfer experiments with aging mice [37], rabbits [38, 39], and hamsters [17] have led to the conclusion that reduced maternal supporting ability with aging results in the decline of litter sizes. Retarded development may result in reduction in implantations and litter sizes in aged hamsters $[7-12,20]$. In our preliminary study, about $25-30 \%$ of decline was observed in litter size of 43-week old hamsters as compared with younger females [20]. About half of this decline in litter size may be caused by the abnormalities in fertilization process, since the abnormality in fertilization observed in the aged hamsters reached to as much as 15\% of the total ova in the present study (asynchronous development of the male and female pronuclei, polyspermy, polygyny and pycnosis were $8.2 \%, 0.4 \%, 5.5 \%$ and $0.4 \%$, respectively).

In summary, the results of the present study indicate that alteration in the progression of ovulation and early fertilization in the aged hamsters may contribute most significantly to large numbers of non-viable ova and the developmental retardation of early embryos. Abnormalities in fertilization, such as a delay in the male pronuclear development and polygyny, probably occur in the aged, less viable oocytes. These abnormalities may represent preimplantation losses in the aged hamsters.

\section{Acknowledgments}

The authors are grateful to Dr. Robert H. Foote, Jacob Gould Schurman Professor Emeritus, Department of Animal Science, Cornell University, for reviewing the manuscript.

\section{References}

1. Talbert GB. Effect of maternal age on reproductive capacity. Am J Obstet Gynecol 1968; 102: 451-477.

2. Jones EC. The aging ovary and its influence on reproductive capacity. J Reprod Fertil Suppl 1970; 12: 17-30.

3. Foote RH. The gametogenic function of the aging ovary in the mammal. In: Blandau RJ (ed.), Aging Gametes. Basel: Karger; 1975: 175-200.

4. Butcher RL, Page RD. Role of the aging ovary in cessation of reproduction. In: Schwartz NB, Hunzicker-Dunn M (eds.), Dynamics of Ovarian Function. New York: Raven Press; 1981: 253-271.

5. Adams CE. Reproductive senescence. In: Austin CR, Short RV (eds.), Reproduction in Mammals,
Book 4: Reproductive Fitness. Cambridge: Cambridge University Press; 1984: 210-233.

6. vom Saal FS, Finch CE. Reproductive senescence: phenomena and mechanisms in mammals and selected vertebrates. In: Knobil E, Neill J (eds.), The Physiology of Reproduction. New York: Raven Press; 1988: 2351-2413.

7. Soderwall AL, Kent HA, Turbyfill CL, Britenbacker AL. Variation in gestation length and litter size of the golden hamster, Mesocricetus auratus. J Geront 1960; 15: 246-248.

8. Blaha GC. Reproductive senescence in the female golden hamster. Anat Rec 1964; 150: 405-412.

9. Thorneycroft IH, Soderwall AL. The nature of the litter size loss in senescent hamsters. Anat Rec 
1969; 165: 343-348.

10. Connors TJ, Thorpe LW, Soderwall AL. An analysis of preimplantation embryonic death in senescent golden hamsters. Biol Reprod 1972; 6: 131-135.

11. Parkening TA, Soderwall AL. Delayed embryonic development and implantation in senescent golden hamsters. Biol Reprod 1973; 8: 427-434.

12. Parkening TA, Soderwall AL. Delayed fertilization and preimplantation loss in senescent golden hamsters. Biol Reprod 1975; 12: 618-631.

13. Jones EC, Krohn PL. The relationships between age, numbers of oocytes and fertility in virgin and multiparous mice. J Endocrinol 1961; 21: 469-494.

14. Matt DW, Sarver PL, Lu JKH. Relation of parity and estrous cyclicity to the biology of pregnancy in aging female rats. Biol Reprod 1987; 37: 421-430.

15. Day JR, La Polt PS, Morales TH, Lu JKH. An abnormal pattern of embryonic development during early pregnancy in aging rats. Biol Reprod 1989; 41: 933-939.

16. Parkening TA, Soderwall AL. Preimplantation stages from young and senescent golden hamsters: presence of succinic dehydrogenase and non-viable ova. J Reprod Fertil 1973; 35: 373-376.

17. Blaha GC. Effect of age of the donor and recipient on the development of transferred golden hamster ova. Anat Rec 1964; 150: 413-416.

18. Parkening TA, Soderwall AL. Delayed fertilization in senescent golden hamsters. Nature 1974; 251: 723-724.

19. Austin CR. Ageing and reproduction: post-ovulatory deterioration of the egg. J Reprod Fertil Suppl 1970; 12: 39-53.

20. Suzuki H, Kida R, Moriguchi M. Effects of age and repeatedly mating on litter size in golden hamsters. Bull Fac Agric Hirosaki Univ 1995; 59: 88-96.

21. Orsini MW. The external vaginal phenomena characterizing the stages of the estrus cycle, pregnancy, pseudopregnancy, lactation and the anestrous hamster, Mesocricetus auratus. Proc Animal Care Panel 1961; 11: 193-206.

22. Xu KP, Greve T. A detailed analysis of early events during in-vitro fertilization of bovine follicular oocytes. J Reprod Fertil 1988; 82: 127-134.

23. BMDP Statistical Software Manual: Release 7. BMDP Statistical Software, 1992, Berkeley: University California Press.

24. Blaha GC, Leavitt WW. Ovarian steroid dehydrogenase histochemistry and circulating progesterone in aged golden hamsters during the estrous cycle and pregnancy. Biol Reprod 1974; 11:
153-161.

25. Mizoguchi H, Dukelow WR. Fertilizability of ova from young or old hamsters after spontaneous or induced ovulation. Fertil Steril 1981; 35: 79-83.

26. Harvey EB, Yanagimachi R, Chang MC. Onset of estrus and ovulation in the golden hamster. I Exp Zool 1961; 146: 231-235.

27. Hunter RHF. Effect of progesterone on fertilization in the golden hamster. J Reprod Fertil 1968; 16: 499-502.

28. Reuter LA, Ciaccio LA, Lisk RD. Progesterone: regulation of estrous cycle, ovulation and estrous behavior in the golden hamster. Endocrinology 1970; 86: 1287-1297.

29. Greenwald GS. Endocrinology of the pregnant hamster. In: Siegel HI (ed.), The Hamster: Reproduction and Behavior. New York: Plenum Press; 1985: 53-72.

30. Yanagimachi R. Mechanisms of fertilization in mammals. In: Mastroianni L, Biggers JD, (eds.), Fertilization and Embryonic Development In Vitro. New York: Plenum Press; 1981: 81-182.

31. Yanagimachi R. Mammalian fertilization. In: Knobil E, Neill J (eds.), The Physiology of Reproduction. New York: Raven Press; 1988: 135-185.

32. Thibault C, Gérard M. Cytoplasmic and nuclear maturation of rabbit oocytes in vitro. Ann Biol Anim Biochim Biophys 1973; 13: 145-156.

33. Masui Y, Clarke HJ. Oocyte maturation. Int Rev Cytol 1979; 57: 185-282.

34. Perreault SD, Barbee RR, Slott VL. Importance of glutathione in the acquisition and maintenance of sperm nuclear decondensing activity in maturing hamster oocytes. Dev Biol 1988; 125: 181-186.

35. Narita A. Endogenous factors affecting sterility in oocytes of aged animals. Jap J Fertil Steril 1995; 40: 57-65.

36. Peluso JJ, Hutz R, England-Charlesworth C. Agerelated alteration in preovulatory oocytes. In: Schwartz NB, Hunzicker-Dunn M (eds.), Dynamics of Ovarian Function. New York: Raven Press; 1981: 303-308.

37. Talbert GB, Krohn PL. Effect of maternal age on viability of ova and uterine support of pregnancy in mice. J Reprod Fertil 1966; 11: 399-406.

38. Adams CE. Aging and reproduction in the female mammal with particular reference to the rabbit. J Reprod Fertil Suppl 1970; 12: 1-16.

39. Maurer RR, Foote RH. Maternal aging and embryonic mortality in the rabbit. I. Repeated superovulation, embryo culture and transfer. J Reprod Fertil 1971; 25: 329-341. 